stages of such a broadly based Model City plan require wide citizen and organizational support. Although experts may recognize needs and suggest appropriate solutions, the final plans should evolve from within the community setting rather than be imposed from without. The citizen's advisory committee can serve a vital role in citing problem areas and program needs, formulating and endorsing plans, enlisting widespread citizen support, resolving major conflicts, educating the public, and serving as advisor to the city and rehabilitation agency officials.

As a program component, effective citizen concern involves organization for citizen action and even participation in community action programs. While public officials and agencies must necessarily control implementation phases and represent the expertise in technical and administrative matters, the total program of uprooting ignorance and poverty and upgrading such areas as health, education, welfare, and housing can work toward achieving the goal of a Model City only if various citizen groups are involved from the early stages of initial planning and programming of projects.

Seldom do responsible officials scoff openly about the use of advisory citizen groups. There is an acute awareness of the useful role of the advisory group in giving a wide variety of citizens an opportunity to participate in their government's affairs. An alternative to this widespread citizen participation is government solely by bureaucratic decisions. Increasingly, "advisoryism" is the democratic way to solicit citizen opinions and the expertise of those who decline to work fulltime for government, to gain participation by those who have complaints, and to involve those who will be directly affected by pending government decisions. The increasing involvement of large numbers of citizens in deciding the major local issues reflects the many faceted problems of the local communities.

\title{
Organizing Citizen Participation
}

\author{
C. J. ROBERTS \\ The University of Oklahoma
}

In January, 1968, after Tulsa had been selected as one of the nation's cities to receive federal support under "Model Cities" legislation, the Director of Tulsa's Model Cities Planning Agency discovered several elements of organization already in existence.

Historically, the service agency in closest contact with the citizenry of the Model Cities area of Tulsa, which included Tulsa's black ghetto, some low-income whites and small fringes of integrated middle-income 
families, was the Tulsa City-County Public Health Service (PHS). To extend to depressed areas a mounting array of health services, the PHS had sent health workers into the field to survey, document, inform, and teach. Because some programs required instruction and cooperation between neighbors, leaders with initiative had been identified. In addition, PHS thoroughly documented vital and socio-economic data on all permanent and, to the greatest extent possible, transient residents.

Other community organizations, such as the Hungry Club, an association of business and professionals holding weekly luncheon meetings, provided forums from which neighborhod organizations could be formed. Often, however, the organizational element was a spokesman tacitly acknowledged by the block, the church, or a social group.

Working from this skeletal framework of leadership, Tulsa Economic Opptortunity Task Force (TEOTF) and its consumers education component, CHOICE, initiated meetings and encouraged neighborhood councils which would afford all residents representation in plans and projects for the community improvement envisioned in the Model Cities proposal. Neighborhood councils sometimes represent several block councils and sometimes are enlarged block councils representing several blocks.

The Model Cities portion of Tulsa for purposes of citizen participation was divided into six areas. Each area council is manned by a delegate representative from the four to seven neighborhood councils within that area.

The area council sends delegates, the number prorated on the number of residents in the area, to the Community Policy and Advisory Commission (CPAC), which is the general forum for the entire Model Cities portion of Tulsa.

The CPAC appoints 21 residents who review proposals and plans formulated by the Model Cities staff. The CPAC is directly answerable to the Mayor and Board of City Commissioners. The Mayor appoints ten additional members who are residents of Tulsa and have expertise germane to the task of community improvement.

At the public meeting in February, 1968, an interim steering committee was elected to established a permanent organization for all concerned Model Cities residents. At a second general meeting for all Model Cities residents a week later, the steering committee, stymied by the inchoate organization of Area and Neighborhood Councils, suggested establishment of a screening committee which would examine nominations to CPAC to insure optimum representation of the Model Cities residents. 
Members of the screening committee were acknowledged leaders familiar with the population distribution in the Model Cities sector. Unfortunately, leaders familiar with the area were also associated with previous unsuccessful attempts to effect neighborhood council organization for community improvement. A hue and cry of some proportion ensued. "The same old crowd is at the controls again." No one really liked the screening council idea, but under the circumstances it seemed the only immediate solution.

Although the screening Council, by the resolution authorizing appointments, was stringently directed towards impartiality, patience, sensitivity, and active interest, the mechanics of yet another deliberative body drew criticism. Presently, the steering committee is holding the screening committee controversy in abeyance and concentrating on completion of organizational ground rules for a citizens' council which will eventually evolve into a non-profit community corporation. This corporation will participate in planning and implementation of all federal programs affecting the area.

Meanwhile, the Model Cities Planning Staff examines needs and resources indicated by statistics, data and input from interim citizen representatives of the district. On this basis, they are formulating plans and proposals which hopefully the plebiscite will approve.

The Model Cities Staff is a group of professionals and their plans and proposals in general will be appropriate. Professionals, however, when unadvised must proceed from theory, and the road between theory and practice is littered with trial-and-error. The concept of Model Cities is that residents in the district, along with the professionals of the Model Cities Planning Staff, should cooperate and coordinate to form theories, plans, and proposals. The professionals, the Model Cities Planning Staff, are the technicians who synchronize wants, needs, resources, and procedure.

\title{
Gitizen Participation: The Process and Its Implications
}

\author{
RICHARD A. WILKEY \\ City Manager's Office, Des Moines, lowa
}

If the residents of the designated Model Neighborhood don't show us they are truly interested in the Model Cities program, we are going to send the grant back to Washington and there won't be any program. This is your program. 